\title{
The Prospect of the Readymade Garments Sector in Bangladesh: Result from Trend Analysis
}

\author{
Afroza Ahammed Shimu ${ }^{1}$, Md. Shahidul Islam ${ }^{2 *}$
}

${ }^{1}$ Senior Assistant Secretary, Research and Development, Bangladesh Knitwear Manufacturers and Exporters Association (BKMEA), Dhaka, BANGLADESH

${ }^{2}$ Mphil Researcher, University of Dhaka, Bangladesh and Senior Assistant Secretary, Research and Development, Bangladesh Knitwear Manufacturers and Exporters Association (BKMEA), Dhaka, BANGLADESH

*E-mail for correspondence: shahidulsoc@gmail.com

Received: May 08, 2016;

Accepted: July 25, 2016;

Published: Nov 05, 2016

Source of Support: Nil

No Conflict of Interest: Declared

\begin{abstract}
Purpose: In Bangladesh readymade garments (RMG) sector, the backbone of the national economy is not the major sources of foreign revenue but a significant role player of the socio-economic development by creating employment opportunities, empowering women and alleviating poverty. In this regard, this paper tries to understand and analyze current situation and structure of the both knitted and woven sectors. After then, this paper predicts the future of both the export and export growth for the next five years.

Methodology: In this study, data on the export and export growth had been collected from the BGMEA. Then the Least Square Method as a trend analysis had been applied to identify forecast export trend and the export growth trend of the both knitwear and woven sector separately. Microsoft excel program had been used for the estimation of the trend analysis alongside with providing predictions for the next five years.

Results: The study found that the trend of both knitwear and woven export was upward. But the study also explored the downward trend of those two knitwear and woven sectors in terms of the growth rate. Moreover, the study showed that after the phasing out of MFA within 2004 and the withdrawal of quota protection, the knitwear export did not face any impediments accorded by the projection.

Implication: This paper will be effective not for understanding the present structure of the RMG sector but helpful to take appropriate policies for the prosperity of the country, especially of this sector.
\end{abstract}

Keywords: RMG, Knitwear, Woven, Export, Growth, Trend, Forecast

\section{INTRODUCTION}

Since late 1980s the Readymade Garments (RMG) sector is the leading exporter of Bangladesh. In terms of exporting RMG products Bangladesh is recently ranked as the second just after China. Due to the low prices, low labor costs, less expensive rent, garments scraps, as well as the standard product quality, Bangladeshi RMG sector has drawn attention from different international and multinational buyers. According to BGMEA 2016, the RMG export is much higher in FY 2014-15 (25491.40 MN.US\$) in comparison with the FY 1992-93 (1445.02 MN.US\$). BGMEA (2016) also shows that the RMG product share increases $77.79 \%$ from FY 1983-84 to FY 2014-15 in the total export. Moreover, this sector has benefitted 4.2 million people by providing direct employment opportunities, of them about $80 \%$ are women (BKMEA, 2016).

Knitwear and woven are two leading categories of Bangladeshi RMG products. Bangladesh has initiated the woven production earlier then the knitted production of the 1990s (Ahmed, 2009). Currently these two products are the top of the Bangladeshi rapid growths. In 2014-15, the export of knitted RMG is 12426.79 MN.US\$ in 2014-15 which is much better than the export of 204.54 MN.US\$ in 1992-1993 (BGMEA, 2016). These two sectors use different types of yarn, fabric, and technologies. The gender lens perspective shows that on the basis of labor types woven sector employs women mostly whilst knitwear sector employs men the most (Ahmed, 2009). The organizational perspective shows that there are two basic types of trade associations for these two categories: BKMEA (Bangladesh Knitwear Manufacturers \& Exporters Association) which deals only with the knitwear sector and BGMEA (Bangladesh Knitwear Manufacturers \& Exporters Association) which deals with overall RMG sectors. Presently both associations have been continuously working on the development of the RMG sectors by facilitating and promoting it.

The manufacturing process of knitted and woven RMG is also different here in Bangladesh. In case of knitted RMG, 
most of raw materials like cotton, yarn, etc. have been imported and then spinning, weaving/knitting, cutting and sewing process completed. In case of woven RMG initially fabrics have been imported and collect from the local market and after then sewing including 'cut, make and trim' completed. Here in Bangladesh there are few local spinning factories which supply the yarn and fabric for knitted RMG. However, the numbers of woven fabric related spinning mills are too small. Unfortunately, these mills do not meet the demand of woven fabric.

Comparatively, woven RMG is more dependent than knitted RMG on imported ingredients (Ahmed, 2009). For example, generally $85 \%$ imported fabric is used in woven RMG while $25 \%$ imported fabrics and yarn used in Knitted RMG. It has been found that the infrastructure of a knit fabrics factory including fabric manufacturing, dyeing and finishing unit requires minimum US $\$ 3.5$ million while the same for a woven factory needs minimum US\$35 million (Quasem, 2002). In case of value addition, the knitwear RMG costs also higher than the woven. Such as, the value addition of knitted RMG was maximum 75\% in 2014 when minimum 30\% was woven (BKMEA, 2016).

Despite providing better employment opportunities RMG sector still faces a lot of obstacles including poor infrastructure, weak government, and low productivity of garments workers (Bhattacharya et al. 2002). More specifically after the Rana Plaza and Tazreen collapse, the intensity of facing national as well as international problems is on the increase. The most notifying fact is the exposure of the worse working condition of the Bangladeshi RMG workers to the buyers. As a result, a severe pressure has been come from the global buyers to increase the social compliance of the RMG industry and threatened to stop buying Bangladeshi product if not happened. Not only that, European Union (EU) has suspended the GSP facility in 2013 which was an opportunity for Bangladesh to get a free access to the EU market (Islam and Maruf, 2014)). Consequently, Bangladeshi RMG export is now in lower position than other competitive countries like India, Pakistan, and Sri Lanka.

Despite lot of worse conditions, Bangladesh government, BKMEA, and BGMEA have been working enormously for the development of this sector. But it is essential to understand the present situation and predict the future trend of the RMG export. In this regard, the main aim of this study is to forecast the export growth for the next five years. Moreover, this paper has also suggested some policies which may help to foster the RMG growth and its export effectively.

\section{LITERATURE REVIEW}

Ahmed et al. (2014) explored that despite political instability and weak government, Bangladesh has been provided favorable environment to enhance the RMG growth. Maximum RMG factories have been providing standard lifestyle to their workers. Additionally, they have positively accepted the competition which has continuously impressed the global buyers on the Bangladeshi products. The Bangladesh government is also supporting to expand the market share in the international markets. Moreover, some of the managerial bodies of RMG factories have been effectively trained up from the abroad. So, now they can impose new technologies along their negotiation capabilities are also increasing.

Wadud et al (2013) evaluated the fire risk safety related issues in the Bangladesh RMG sector. The study exposed that generally the member RMG industries of the Trade Union have practiced more than the non-members. A Ushaped relationship between fire risk index and the industry size was also identified by the study.

Haque et al. (2011) studied on the supply chain performance of the Bangladeshi RMG industry. The study found that overall supply chain performance was not good enough. Moreover, they recommended how Bangladesh can develop the supply chain performance of the Bangladeshi RMG industry. In this regard, the study emphasized on improving the backward linkage, labor, production line efficiency to progress the supply chain performance.

Nuruzzaman and Haque (2009) explored the business process and the lead time of the garments export. They found that import dependency was the main reason for the longer lead time. They also explained that the industry should ensure fabrics collection from the local market as well as establish new textile to produce fabrics at local level in order to ease lead time.

Haque (2002) examined the problems and prospects of the Bangladeshi RMG products in the global market. He found that USA, European Union, Canada were more Suitable for the RMG product export. He had also mentioned about India, Thailand, China and Vietnam as prime competitors of Bangladesh.

Ahmed (2009) examined the growth, challenge and performance of the RMG sector during post Multi-Fibre Arrangement (MFA). Not long ago, the Bangladeshi RMG product, based on the agreement exported into the international market with pacific facilities. Previously, this agreement ensured the Bangladesh RMG product exported into the international market by giving pacific facility. But without this Quota, RMG export may have hampered. He recommended that both governmental and private sectors should take proper strategies/ tragedyby which the damage could be prevented in absence of quota.

Ahmed (2013) found that about 78\% export revenue of Bangladesh come from the Bangladeshi RMG products. This sector has vast effect not in eradicating poverty but in gaining foreign money. He suggested a vast enhancing the efficacy of the RMG sector, social compliance issues, etc. to improve the workplace environment.

Baral (2010) mentioned about the compliance including proper labor rights and facilities could provide positive output in the RMG sector. He explored that complaint 
RMG factories have the higher turnover in comparing with the non-complaint factories. He suggested that the factories should be compliant not only for maximizing profit but also for protecting the human rights of the workers.

Haider (2007) found that China and India were the major competitors of the Bangladeshi RMG product. Maintaining the competition during post-suspension of the export quota in 2005, the industry should shorten the lead time of production. Bangladesh should focus on social compliance issues as per the codes of conduct. Moreover, the government should take major steps to develop the RMG infrastructure for the positive and sustainable growth. Abolishing corruption and political instability should be assured for the development of this sector.

\section{DATA AND METHODS}

The research was based on the secondary data. The data was collected from government sources, Export Promotion Bureau, BGMEA, BKMEA, International Trade Corporation, journal, books, articles and newspapers. The export and export growth of the RMG data was collected from BGMEA. Moreover, trend analysis as the least square method was applied to forecast the export trend and the export growth trend of both knitwear and woven sectors separately. Excel program was used to find the present and predict the trend. The export trend was predicted for the next five years.

\section{RESULT}

Trend Analysis of Knitwear Export:
The least square method was applied to conduct the trend analysis of the knitwear export. In accordance with the forecasting formula, time was considered as the independent variable and the value of the time series was the dependent variable (Chowdhury et al, 2014).

\section{LINEAR TREND EQUATION: $\mathrm{Y}^{\prime}=\mathbf{a}+\mathbf{b t}$}

Where,

$\mathrm{Y}^{\prime}=$ the projected value of the $\mathrm{Y}$ variable for a selected value of $t$. Here $Y^{\prime}$ is the projected value of Knitwear exports.

$\mathrm{a}=$ It is known as the $\mathrm{Y}$-intercept and the estimated value of $Y$ when $t=0$ or it is the estimated value of $\mathrm{Y}$ where the line crosses the $\mathrm{Y}$ axis and $t$ is zero

$b=b$ is called the slope of the line or it is the average change in $Y^{\prime}$ for each change of one unit in $t$. Here $t$ is any value of time that is selected.

Using excel method the study got the value of intercept and the value of slope which are as follows 4164.2 and 560.81 respectively. By substituting the value of slope and intercept the study gets the trend equation as follows:

\section{$Y^{\prime}=4164.2+560.81(t)$}

The overall calculation is presented on table 1. (See appendix)

The amount of knitwear exports, trend and forecasted values of knitwear exports are graphically presented below:

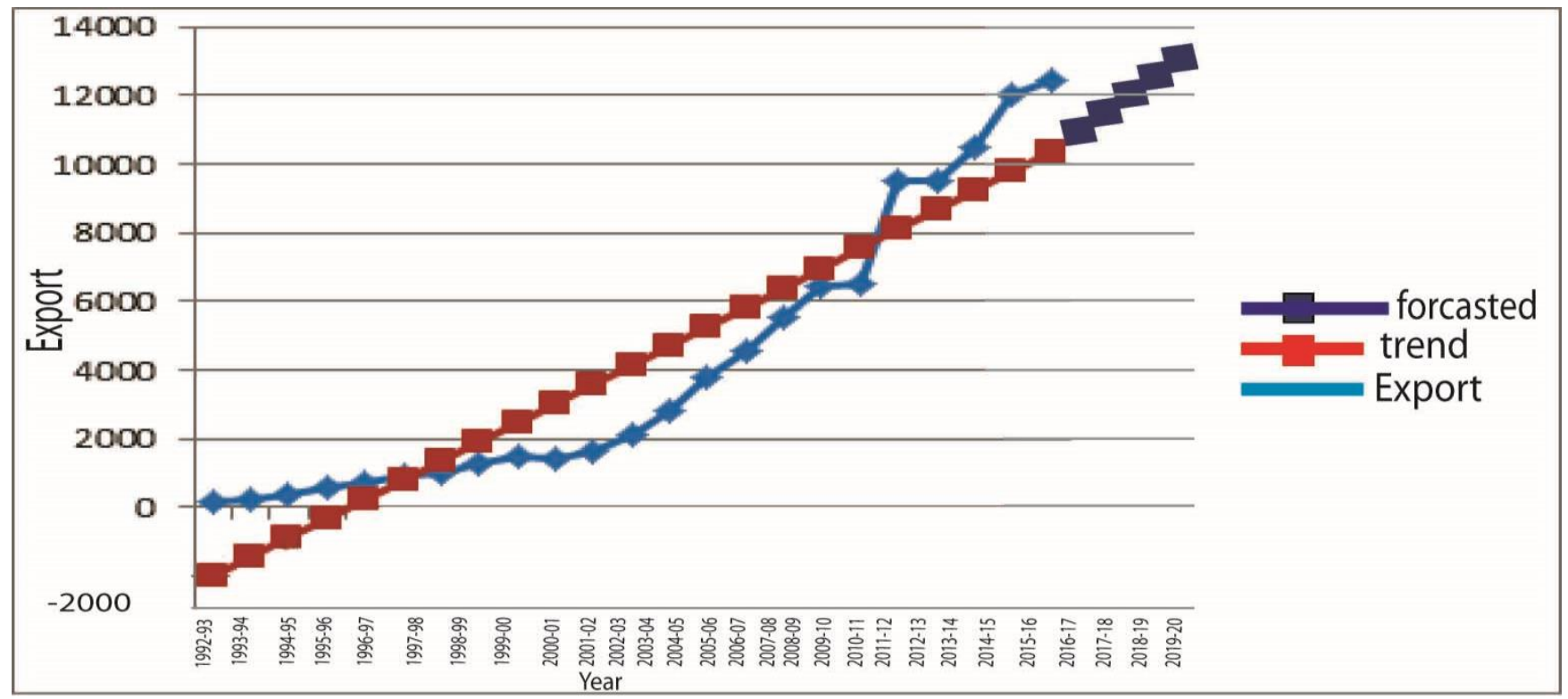

Here, the $\mathrm{X}$ axis represents the fiscal years and the $\mathrm{Y}$ axis symbolizes the amount of knitwear exports.

\section{Findings}

The study found from the graphical representation that knitwear export curve was upward sloping which means that knitwear export was increasing day by day. The lion share of knitwear product went to EU, USA, UK,
Germany, and France market. Top ten knitwear items exported to the world included HS code 610910, 611090, 611020, 610510, 610462, 611030, 610990, 610342, 610821 and 610711(EPB, 2015). In 1990, the knitwear sector developed significantly. Alongside with that the knitwear 
export started to achieve robust growth mainly afterwards 1990s. The statistics of table 1 showed that the export of knitwear products was only US\$204.54 million in FY 1992-93 and outstandingly this amount risen to US\$12426.79 million in FY 2014-15 that was sixty times more than the amount of knitwear export in FY 1992-93.

Despite the withdrawal of the Canadian quota system in 2003 and the phase-out of export- quota system in 2005, the export value was also enhancing but after FY 2008-09, the flow of export was comparatively slow.

After using the least square method the predicted value of the Knitwear export was US\$10893.92 million, US\$11454.73 million, US\$12015.54 million, US\$12576.35 million, US\$13137.16 million in FY 2015-16, FY2016-17, FY 2017-18, FY 2018-19 and FY 2019-20 respectively. Thus way, the overall scenario indicated the positive trend of Bangladeshi knitwear exports.

Trend Analysis of the Woven Wear Export: The least square method used for the trend analysis of the woven wear industries' export. According to the forecasting method, time was considered as the independent variable and the value of the time series was considered as the dependent variable.

\section{LINEAR TREND EQUATION: $\mathbf{Y}^{\prime}=\mathbf{a}+\mathbf{b t}$}

Where,

$\mathrm{Y}^{\prime}=$ the projected value of the $\mathrm{Y}$ variable for a selected value of $t$. Here $Y^{\prime}$ is the projected value of Woven wear exports.

$\mathrm{a}=\mathrm{It}$ is called the Y-intercept and the estimated value of $Y$ when

$t=0$ or it is the estimated value of $Y$ where the line crosses the $\mathrm{Y}$ - axis and $\mathrm{t}$ is zero

$b=b$ is called the slope of the line or it is the average change in

$\mathrm{Y}^{\prime}$ for each change of one unit in $\mathrm{t}$. Here $\mathrm{t}$ is any value of time that is selected.

Using excel method the study gets the value of intercept and the value of slope which are as follows 4990.05 and 471.52 respectively. By substituting the value of slope and intercept the study gets the trend equation as follows:

$Y^{\prime}=4990.05+471.52(t)$

The overall calculation is presented on table 2. (See appendix)

The amount of Woven Wear exports, trend and forecasted values of Woven Wear exports are graphically presented below.

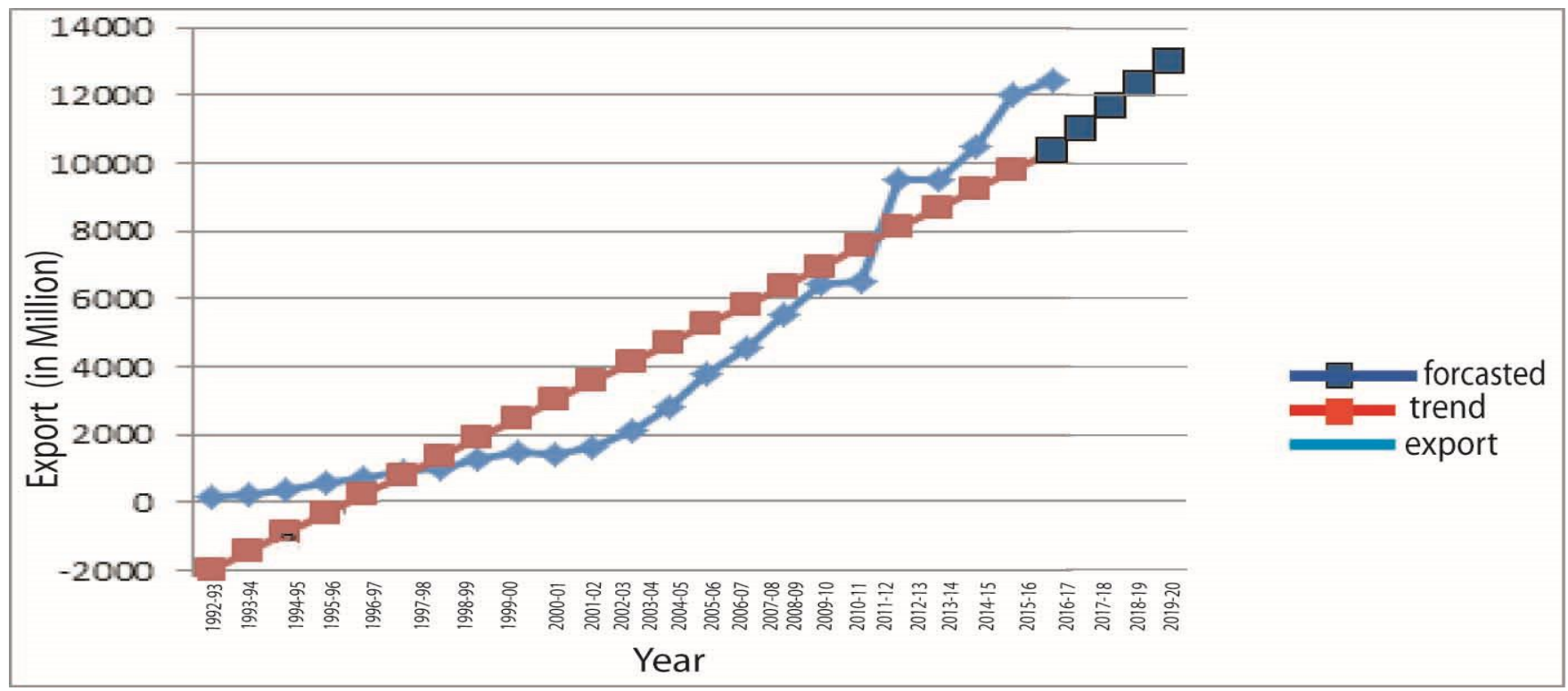

The $\mathrm{X}$ axis symbolizes the fiscal years and the $\mathrm{Y}$ axis symbolizes the amount of woven wear exports.

\section{Findings}

The graphical presentation exposes the upward sloping curve of the woven wear export curve which consequently represents the positive trend. Table 02 explains that the amount of woven wear export in FY 2014-15 was ten times higher than the amount of same in FY 1992-93. Similarly in case of the knitwear items, the major share of woven wear items supplied to EU, Germany, USA, UK, France markets (EPB, 2015).Top ten woven wear items exported to the world included HS code 620342, 620462, 620520, 620590, 620469, $620349,620333,621210,620343$ and 620193 wherein woven wear item of HS code 620469, 620349 and 620333 showed negative export growth rate in FY 2013-14 (EPB and ITC). The major woven wear items included trousers, shirts, jacket, blazers etc.

The withdrawal of quota system in 2003 and the phaseout of export-quota system in 2005 could not deter the export flow of woven wear items. According to table-02 the export of woven wear products was only US $\$ 1240.48$ million in FY 1992-93 and this amount rose to US\$ 13064.61million in FY 2014-15. 
The predicted value of woven wears export were US\$10648.29 million, US\$11119.81 million, US\$11591.33 million, US\$12062.85 million and US\$12534.37 million in FY 2015-16, FY2016-17, FY 2017-18, FY 2018-19 and FY 2019-20 respectively. However, the overall scenario indicated a positive trend of woven wear exports of Bangladesh.

Trend Analysis of the growth rate of Knitwear Export: The study was conducted by using least square method to do the trend analysis of the growth rate of knitwear export. Accorded by the forecasting method, time was considered as the independent variable and the value of the time series was considered as the dependent variable.

\section{LINEAR TREND EQUATION: $Y^{\prime}=\mathbf{a}+\mathbf{b t}$}

Where,

$\mathrm{Y}^{\prime}=$ the projected value of the $\mathrm{Y}$ variable for a selected value of $t$.
Here $Y^{\prime}$ is the projected value of growth rate of knitwear export

$\mathrm{a}=\mathrm{It}$ is called $\mathrm{Y}$-intercept and the estimated value of $Y$ when $t=0$ or it is the estimated value of $Y$ where the line crosses the $\mathrm{Y}$-axis and $\mathrm{t}$ is zero

$b=b$ is called the slope of the line or it is the average change in $Y^{\prime}$ for each change of one unit in $t$. Here $t$ is any value of time that is selected.

Using excel method the study gets the value of intercept and the value of slope which are as follows 21.07 and 1.17 respectively. By substituting the value of slope and intercept the study gets the trend equation as follows:

$\mathrm{Y}^{\prime}=21.07-1.17(\mathrm{t})$

The overall calculation is presented on table 3. (See appendix)

The growth rate of knitwear exports, trend and forecasted values of the knitwear exports are graphically presented below.

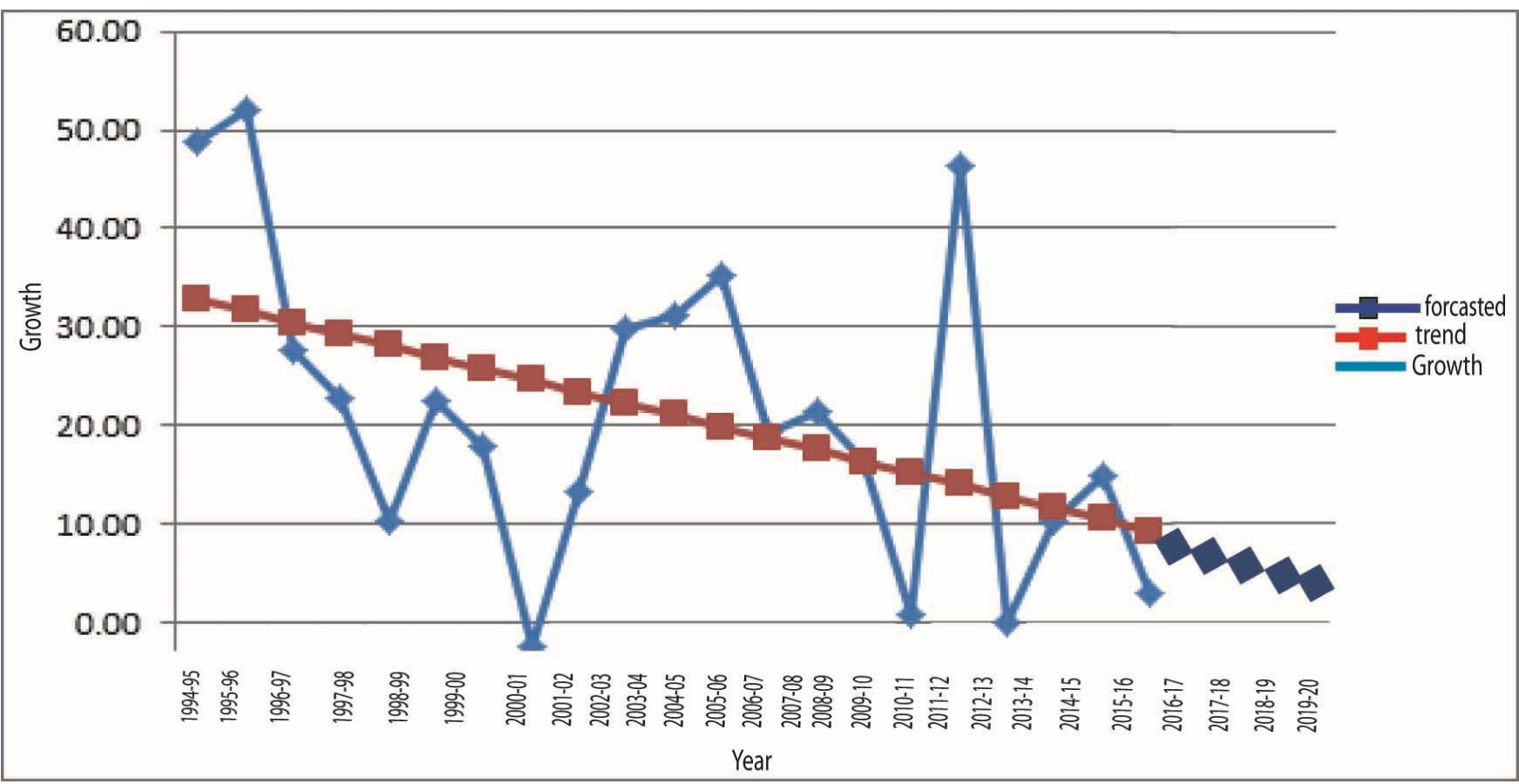

The $\mathrm{X}$ axis symbolizes the fiscal years and the $\mathrm{Y}$ axis symbolizes the amount of growth rate of knitwear exports.

\section{Findings}

The graphical representation explains the downward sloping curve of the knitwear export curve which consequently represents the slowdown trend from the boom periods. In this regard, the slowdown trend of the growth rate scenario was usual for the fast growing sectors.

Table 03 elaborates that the growth rate of knitwear export was presenting the maximum value in FY 1995-96. From then the development of the knitwear sector initiated significantly. Another notifying growth rate was noticeable in FY 2010-11 as a result of distinguishing knitwear as largest export earning sector. The total situation presented the negative growth rate of knitwear sector only in FY 2001-02. Due to the 9/11 incidents of
2001, the value of RMG exports to the USA was affected badly and RMG export was 12\% lower in FY 2001-02 in comparison with FY 2000-01(Haque, 2002). After the phasing out of MFA by 2004 and the withdrawal of quota protection, the growth rate of knitwear export was not hindered accorded by the projection.

By using the least square method the predicted value of the growth rate of knitwear export were $8.22 \%, 7.06 \%$, $5.89 \%, 4.72 \%$ and $3.55 \%$ in the respective FY 2015-16, FY2016-17, FY 2017-18, FY 2018-19 and FY 2019-20. This explains the declining growth rate of the knitwear export.

Trend Analysis of the growth rate of Woven Wear Export: The research was conducted by using least square method to conduct the trend analysis of the growth rate 
of the woven wear export. In accordance with the forecasting method, time was regarded as the independent variable and the value of the time series was regarded as the dependent variable.

\section{LINEAR TREND EQUATION: $Y^{\prime}=a+b t$}

Where,

$\mathrm{Y}^{\prime}=$ the projected value of the $\mathrm{Y}$ variable for a selected value of $\mathrm{t}$.

Here $\mathrm{Y}^{\prime}$ is the projected value of growth rate of woven wear export

$\mathrm{a}=\mathrm{It}$ is called $\mathrm{Y}$-intercept and the estimated value of $Y$ when $t=0$ or it is the estimated value of $Y$ where the line crosses the $\mathrm{Y}$-axis and $\mathrm{t}$ is zero $b=b$ is called the slope of the line or it is the average change in $Y^{\prime}$ for each change of one unit in $t$. Here $t$ is any value of time that is selected.

Using excel method the study gets the value of intercept and the value of slope which are as follows 12.21 and 0.13 respectively. By substituting the value of slope and intercept the study gets the trend equation as follows:

$Y^{\prime}=12.21-0.13(t)$

The overall calculation is presented in Table 4. (See appendix)

The growth rate of the woven wear export, trend and forecasted values of the growth rate of the woven wear exports are graphically presented below.

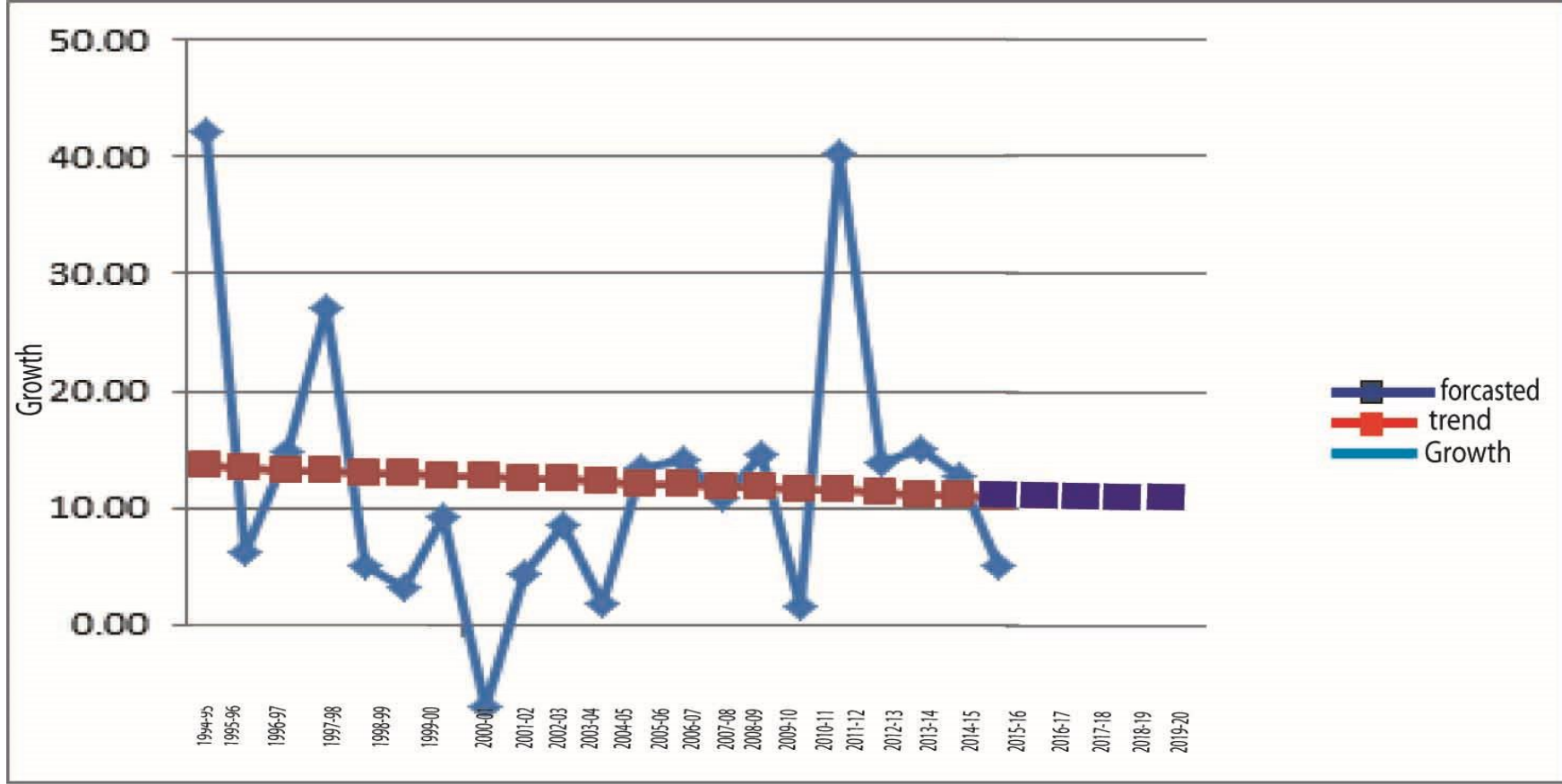

Year

The $\mathrm{X}$ axis symbolizes the fiscal years and the $\mathrm{Y}$ axis symbolizes the amount of growth rate of woven wear exports.

\section{Findings}

The graphical representation explains the downward sloping curve of the woven wear export. This is not alarming because it is well known that the slowdown of growth rate scenario is usual for the fast growing sectors.

Table 04 elaborates that the growth rate of woven wear export was presenting the maximum value in FY 1994-95. Although there was an existence of the financial crisis of the USA in 2007 and the worldwide economic recession from the second half of 2008, the export growth of woven wear items was quiet better. For instance, in FY 2010-11, the export growth rate was about $40.23 \%$.

In terms of maintaining harmony with the knitwear sector, woven wear sector as a consequence of 9/11 incident, faced negative export growth rate in FY 2001-02 which was $-7.12 \%$. Moreover, phasing out of MFA and withdrawal of quota protection and Rana Plaza incidence export growth rate of woven wear item is still significant. By using the least square method the forecasted values of growth rate of woven wear export were $10.78 \%, 10.65 \%$, $10.52 \%, 10.39 \%$ and $10.26 \%$ in the respective FY 2015-16, FY2016-17, FY 2017-18, FY 2018-19 and FY 2019-20. Thus way, the total condition indicates the declining growth rate over time.

\section{COMPARATIVE DISCUSSION BETWEEN KNITWEAR AND WOVEN WEAR EXPORT AND EXPORT GROWTH}

Knitwear consignment in 1973 played the vital role in the initiation of the RMG business. From the very beginning acceleration of this robust sector was made by woven garments when the contribution of knitwear sector was very tiny (Yunus, 2002). Table 5 explains that in FY 199495 share of knitwear in RMG export was $17.65 \%$ where 
share of woven wear in RMG was $82.35 \%$ which was four times more than knitwear share. Overwhelmingly, this share of knitwear had started to overcome the share of woven wear in FY 2007-08 and the contribution of knitwear and woven wear sector was almost similar in FY 2014-15.The difference between share of knitwear in Bangladesh export and share of woven wear in Bangladesh export started declining notably from FY 2004-05.

Presently, knitwear is one of the largest exports earning sector of Bangladesh. This sector is contributing 39.83\% to national export earnings and carrying out $6.38 \%$ share in GDP. From FY 2003-04 to FY 2014-15 the Cumulative average Growth Rate of the knitwear sector was $15.75 \%$. The latest data shows that In July 2015-16 FY the amount of knitwear export was US\$1307.9 million which is US\$97.82 million more than woven wear export (Table-5).

In terms of backward linkages, strong backward linkages are established for the purpose of keeping pace with the progress of export-oriented knitwear sector in knitwear sector from last previous years. Woven wear sectors are lagging behind in this case due to the strong dependency for raw materials on external sources. Thus way, value addition of knitwear sector almost arises to $75 \%$ inside the country where value addition of woven sector is only $30 \%$ inside the country. The analysis indicates that the strong backward linkage, rising trend of value addition and worldwide expanded demands of knitwear items bring the sector at this stage and grabbing the position of woven sector gradually and entirely.

\section{RECOMMENDATIONS}

- To meet the rapidly growing demand of international buyers on relevant issues including compliance, fire safety, workplace safety, building safety and Green industry development (GID) etc., the production cost of RMG sector is presenting the upward trend. Consequently the profit margin is going down. For that, it is necessary to conduct an intensive market research for the maintenance of the standard profit margin.

- $\quad$ For the purpose of getting permit and certificates for duly import and export, procedural obstacles are major impediments for this sector in this regard. Thus automation and single window system will be much more effective to mitigate existing procedural obstacles.

- Lead time minimization is a primary challenge for RMG sector. Infrastructural development and digitalized port facilities are badly needed to overcome the problem.

- Eco-friendly technologies could be the strategic options in the upcoming days to cope with the global changing scenario of the textile trade

- For the purpose of working with the environmental issues, cleaner production mechanism, energy efficiency, effluent treatment plan which are related with SDGs, government and banking sectors should provide loan and incentive, especially towards small factories.

- Though woven garments are still dominating the export earnings of Bangladesh but the increase of the knitted items production is remarkable rate with $40 \%$ export earnings, which should be maintained by proper assistance.

- Knitwear export is increasing in terms of quantity but the sector is lagging behind in terms of price while the situation is reverse for woven sector. To maintain the positive trend of knitwear export product diversification is needed to increase the price in global market.

- Though Knitwear export show positive trend but to sustain in global market this sector need govt. support. This would be beneficiary if source tax is imposed on cutting and making price rather than Free on Board (FOB) price.

- In terms of backward linkages knitwear sectors (knitting, dyeing, printing, weaving, cutting, and sewing) is less import in comparing with the woven wear sector (cutting, making, and packing). Consequently the value addition increase of woven wear sector backward linkages should be established domestically.

- One of the major challenges for woven wear sector is dependency on external sources for backward linkages (cutting, making, and packing).Higher import price of raw materials decrease the value addition in domestic market. Govt. should waive the import duty on raw material for woven wear sector.

- Tax waiver on import of fire safety equipment is urgently needed to ensure safety for workers which can foster the overall RMG export.

- Moreover cost effective strategy, new product development strategy, and market diversification strategy should be considered completely.

\section{REFERENCES}

Ahmed, F.Z., Greenleaf, A. and Sacks, A., 2014. The paradox of export growth in areas of weak governance: The case of the readymade garment sector in Bangladesh. World Development, 56, pp.258-271

Ahmed, N., Nasima, M., \& Alam, N. (2013). Socio-Business Consideration of Garment Workers in Bangladesh: A Statistical Review. ABC Journal Of Advanced Research, 2(2), 8 - 17.

Alam, A. (2016). Organizational Culture: An Empirical Study on Selected Garment Factories in Bangladesh. Asian Business Review, 6(2), 73-78. doi: http://dx.doi.org/10.18034/abr.v6i2.823

Baral, L.M., 2010. Comparative study of compliant \& noncompliant RMG factories in Bangladesh. International Journal of Engineering \& Technology, IJRT-IJENs, 10(2). Haider, M. Z. (2007). Competitiveness of the Bangladesh ready-made garment industry in major international markets. AsiaPacific Trade and Investment Review, 3(1), 3-27 
Bhattacharya, D., Rahman, M. and Raihan, A., 2002. Contribution of the RMG Sector to the Bangladesh Economy. CPD Occasional Paper Series,50, p.6.

Chowdhury, M.M,. Ahmed, R., Yasmin., M (2014). Prospects and Problems of RMG Industry: A study on Bangladesh. Research Journal of Finance and Accounting. s5(7):103-118.

Chowdhury, S. (2015). The Necessities of HR practices in RMG Sector of Bangladesh (7-20). Asian Accounting \& Auditing Advancement, 1(1), 7-20.

Haque, A., 2002. Global Marketing of Readymade Garment Products from Bangladesh: Market Prospect and Challenges. Pakistan Journal of Applied Sciences, 2(10), pp.975979.Ahmed, N. (2009). Sustaining ready-made garment exports from Bangladesh. Journal of Contemporary Asia, 39(4), 597-618.

Haque, A.S., 2002. IMPACT OF GLOBAL CHANGES ON THE TEXTILE INDUSTRY OF BANGLADESH. Journal of International Affairs, 6(3), p.102.

Haque, K.M.A., Hossain, M.M., Hossain, M.S.J., Islam, M.A., Hassan, M., Shamshuzzaman, M. and Hossain, M.D., 2011. Performance Evaluation of Bangladeshi Apparel and Textile Supply Chain Network, A Case Study.Performance Evaluation, 1(1), pp.211-218.
Quasem, A.S.M. (2002) "Backward Linkages in the Textile and Clothing Sector of Bangladesh," Paper presented at the Executive Forum on National Export Strategies, jointly organised by ITC and SECO, Montreux, Switzerland, 25-8 September.

Rouf MA, Hasan MS and Ahmed AA. 2014. Financial Reporting Practices in the Textile Manufacturing Sectors of Bangladesh ABC Journal of Advanced Research, 3, 57-67.

Saha, A., \& Mondal, K. (2015). Internal Control Practices of Readymade Garments Sector (Textile Industry) in Bangladesh. Asian Business Review, 1(1), 67-71. doi:http://dx.doi.org/10.18034/abr.v1i1.338

Wadud, Z., Huda, F.Y. and Ahmed, N.U., 2014. Assessment of fire risk in the readymade garment industry in Dhaka, Bangladesh. Fire Technology,50(5), pp.11271145.Nuruzzaman, M., \&Haque, A. K. M. (2009). Lead time management in the garment sector of Bangladesh: An avenues for survival and growth.European Journal of Scientific Research, 33(4), 617-629.

Yunus, M., 2010. Knitwear Industry in Bangladesh: A Case Study of Firms in Narayanganj. A report prepared by Bangladesh Institute of Development Studies (BIDS).

\section{APPENDICES}

Table 1: Calculation of trend of knitwear export of Bangladesh

\begin{tabular}{|c|c|c|c|}
\hline YEAR & Knitwear export (million US\$) Y & Trend value & Forecasted values of no. of Knitwear export \\
\hline $1992-93$ & 204.54 & -2004.71 & \\
\hline 1993-94 & 264.14 & -1443.9 & \\
\hline 1994-95 & 393.26 & -883.09 & \\
\hline $1995-96$ & 598.32 & -322.28 & \\
\hline $1996-97$ & 763.3 & 238.53 & \\
\hline $1997-98$ & 937.51 & 799.34 & \\
\hline $1998-99$ & 1035.02 & 1360.15 & \\
\hline 1999-00 & 1268.22 & 1920.96 & \\
\hline 2000-01 & 1495.51 & 2481.77 & \\
\hline $2001-02$ & 1458.93 & 3042.58 & \\
\hline $2002-03$ & 1653.82 & 3603.39 & \\
\hline $2003-04$ & 2148.02 & 4164.2 & \\
\hline 2004-05 & 2819.47 & 4725.01 & \\
\hline $2005-06$ & 3816.98 & 5285.82 & \\
\hline $2006-07$ & 4553.6 & 5846.63 & \\
\hline $2007-08$ & 5532.52 & 6407.44 & \\
\hline 2008-09 & 6429.26 & 6968.25 & \\
\hline $2009-10$ & 6483.29 & 7529.06 & \\
\hline $2010-11$ & 9482.06 & 8089.87 & \\
\hline 2011-12 & 9486.35 & 8650.68 & \\
\hline $2012-13$ & 10475.88 & 9211.49 & \\
\hline 2013-14 & 12049.81 & 9772.3 & \\
\hline 2014-15 & 12426.79 & 10333.11 & \\
\hline $2015-16$ & & & 10893.92 \\
\hline $2016-17$ & & & 11454.73 \\
\hline $2017-18$ & & & 12015.54 \\
\hline 2018-19 & & & 12576.35 \\
\hline $2019-20$ & & & 13137.16 \\
\hline Intercept & 4164.2 & & \\
\hline slope & 560.81 & & \\
\hline
\end{tabular}


Table 2: Calculation of trend of woven wear export of Bangladesh

\begin{tabular}{|c|c|c|c|}
\hline YEAR & woven export (million US\$) Y & Trend value & Forecasted values of no. of woven export \\
\hline $1992-93$ & 1240.48 & -196.67 & \\
\hline 1993-94 & 1291.65 & 274.85 & \\
\hline $1994-95$ & 1835.09 & 746.37 & \\
\hline $1995-96$ & 1948.81 & 1217.89 & \\
\hline $1996-97$ & 2237.95 & 1689.41 & \\
\hline $1997-98$ & 2844.43 & 2160.93 & \\
\hline 1998-99 & 2984.96 & 2632.45 & \\
\hline 1999-00 & 3081.19 & 3103.97 & \\
\hline $2000-01$ & 3364.32 & 3575.49 & \\
\hline $2001-02$ & 3124.82 & 4047.01 & \\
\hline $2002-03$ & 3258.27 & 4518.53 & \\
\hline $2003-04$ & 3538.07 & 4990.05 & \\
\hline $2004-05$ & 3598.2 & 5461.57 & \\
\hline $2005-06$ & 4083.82 & 5933.09 & \\
\hline $2006-07$ & 4657.63 & 6404.61 & \\
\hline $2007-08$ & 5167.28 & 6876.13 & \\
\hline $2008-09$ & 5918.51 & 7347.65 & \\
\hline $2009-10$ & 6013.43 & 7819.17 & \\
\hline $2010-11$ & 8432.4 & 8290.69 & \\
\hline 2011-12 & 9603.34 & 8762.21 & \\
\hline $2012-13$ & 11039.85 & 9233.73 & \\
\hline 2013-14 & 12442.07 & 9705.25 & \\
\hline 2014-15 & 13064.61 & 10176.77 & \\
\hline 2015-16 & & & 10648.29 \\
\hline 2016-17 & & & 11119.81 \\
\hline 2017-18 & & & 11591.33 \\
\hline 2018-19 & & & 12062.85 \\
\hline 2019-20 & & & 12534.37 \\
\hline Intercept & 4990.05 & & \\
\hline slope & 471.52 & & \\
\hline
\end{tabular}

Table-3: Calculation of trend of knitwear growth rate

\begin{tabular}{|c|c|c|c|}
\hline YEAR & Growth rate Knitwear Y & Trend value & Forecasted values of no. of Growth rate Knitwear \\
\hline $1994-95$ & 48.88 & 32.77 & \\
\hline $1995-96$ & 52.14 & 31.6 & \\
\hline $1996-97$ & 27.57 & 30.43 & \\
\hline $1997-98$ & 22.82 & 29.26 & \\
\hline $1998-99$ & 10.40 & 28.09 & \\
\hline $1999-00$ & 22.53 & 26.92 & \\
\hline $2000-01$ & 17.92 & 25.75 & \\
\hline $2001-02$ & -2.45 & 24.58 & \\
\hline $2002-03$ & 13.36 & 23.41 & \\
\hline $2003-04$ & 29.88 & 22.24 & \\
\hline $2004-05$ & 31.26 & 21.07 & \\
\hline $2005-06$ & 35.38 & 19.9 & \\
\hline $2006-07$ & 19.30 & 18.73 & \\
\hline $2007-08$ & 21.50 & 17.56 & \\
\hline $2008-09$ & 16.21 & 16.39 & \\
\hline $2009-10$ & 0.84 & 15.22 & \\
\hline $2010-11$ & 46.25 & 14.05 & \\
\hline $2011-12$ & 0.05 & 12.88 & \\
\hline $2012-13$ & 10.43 & 11.71 & \\
\hline $2013-14$ & 15.02 & 10.54 & \\
\hline $2014-15$ & 3.13 & 9.37 & \\
\hline $\mathbf{2 0 1 5 - 1 6}$ & & & $\mathbf{8 . 2 2}$ \\
\hline $\mathbf{2 0 1 6 - 1 7}$ & & & $\mathbf{3 . 0 6}$ \\
\hline $\mathbf{2 0 1 7 - 1 8}$ & & & \\
\hline $\mathbf{2 0 1 8 - 1 9}$ & $\mathbf{2 1 . 0 7}$ & & \\
\hline $\mathbf{2 0 1 9 - 2 0}$ & $\mathbf{1 . 1 7}$ & & \\
\hline Intercept & & & \\
\hline slope & & & \\
\hline
\end{tabular}


Table 4 Calculation of trend of woven growth rate

\begin{tabular}{|c|c|c|c|}
\hline YEAR & Growth rate woven Y & Trend value & Forecasted values of no. of Growth rate woven \\
\hline $1994-95$ & 42.07 & 13.51 & \\
\hline $1995-96$ & 6.20 & 13.38 & \\
\hline $1996-97$ & 14.84 & 13.25 & \\
\hline $1997-98$ & 27.10 & 13.12 & \\
\hline $1998-99$ & 4.94 & 12.99 & \\
\hline $1999-00$ & 3.22 & 12.86 & \\
\hline $2000-01$ & 9.19 & 12.73 & \\
\hline $2001-02$ & -7.12 & 12.6 & \\
\hline $2002-03$ & 4.27 & 12.47 & \\
\hline $2003-04$ & 8.59 & 12.34 & \\
\hline $2004-05$ & 1.70 & 12.21 & \\
\hline $2005-06$ & 13.50 & 12.08 & \\
\hline $2006-07$ & 14.05 & 11.95 & \\
\hline $2007-08$ & 10.94 & 11.82 & \\
\hline $2008-09$ & 14.54 & 11.69 & \\
\hline $2009-10$ & 1.60 & 11.56 & \\
\hline $2010-11$ & 40.23 & 11.43 & \\
\hline $2011-12$ & 13.89 & 11.3 & \\
\hline $2012-13$ & 14.96 & 11.17 & \\
\hline $2013-14$ & 12.70 & 11.04 & \\
\hline $2014-15$ & 5.00 & 10.91 & \\
\hline $2015-16$ & & & \\
\hline $2016-17$ & & & \\
\hline $2017-18$ & & & \\
\hline $2018-19$ & & & \\
\hline $2019-20$ & 12.21 & & \\
\hline Intercept & -0.13 & & \\
\hline slope & & & \\
\hline
\end{tabular}

Table 5: Percentage share of RMG in total BD Export and percentage share in GDP

\begin{tabular}{|l|l|l|l|l|l|l|}
\hline $\begin{array}{l}\text { Fiscal } \\
\text { Year }\end{array}$ & \multicolumn{2}{|c|}{$\begin{array}{l}\text { Share in RMG } \\
\text { Export (\%) }\end{array}$} & \multicolumn{2}{l|}{$\begin{array}{l}\text { Share in BD } \\
\text { Export (\%) }\end{array}$} & Overall RMG \\
\hline & Knitwear & woven & Knitwear & Woven & $\begin{array}{l}\text { Total BD Export } \\
\text { (In million US\$) }\end{array}$ & $\begin{array}{l}\text { Share in } \\
\text { GDP (\%) }\end{array}$ \\
\hline $94-95$ & 17.65 & 82.35 & 11.32 & 52.85 & 3472.56 & 5.87 \\
\hline $95-96$ & 23.49 & 76.51 & 15.41 & 50.20 & 3882.42 & 6.25 \\
\hline $96-97$ & 25.43 & 74.57 & 17.28 & 50.65 & 4418.28 & 7.09 \\
\hline $97-98$ & 24.85 & 75.15 & 18.22 & 55.09 & 5161.2 & 8.59 \\
\hline $98-99$ & 25.75 & 74.25 & 19.49 & 56.18 & 5312.86 & 8.79 \\
\hline $99-00$ & 29.18 & 70.82 & 22.08 & 53.59 & 5752.2 & 9.24 \\
\hline $00-01$ & 30.78 & 69.22 & 23.14 & 52.02 & 6467.3 & 11.06 \\
\hline $01-02$ & 31.83 & 68.17 & 24.38 & 52.20 & 5986.09 & 9.64 \\
\hline $02-03$ & 33.67 & 66.33 & 25.26 & 49.76 & 6548.44 & 9.46 \\
\hline $03-04$ & 37.78 & 62.22 & 28.25 & 46.54 & 7602.99 & 10.07 \\
\hline $04-05$ & 43.93 & 56.07 & 32.58 & 41.58 & 8654.52 & 10.63 \\
\hline $05-06$ & 48.31 & 51.69 & 36.26 & 38.80 & 10526.2 & 12.74 \\
\hline $06-07$ & 49.44 & 50.56 & 37.39 & 38.25 & 12177.9 & 13.45 \\
\hline $07-08$ & 51.71 & 48.29 & 39.21 & 36.62 & 14110.8 & 13.44 \\
\hline $08-09$ & 52.07 & 47.93 & 41.30 & 38.02 & 15565.19 & 13.81 \\
\hline $09-10$ & 51.88 & 48.12 & 40.01 & 37.11 & 16204.65 & 12.45 \\
\hline $10-11$ & 52.93 & 47.07 & 41.36 & 36.78 & 22924.38 & 16.00 \\
\hline $11-12$ & 49.69 & 50.31 & 39.06 & 39.54 & 24287.66 & 16.31 \\
\hline $12-13$ & 48.69 & 51.31 & 38.76 & 40.85 & 27027.36 & 16.57 \\
\hline $13-14$ & 49.20 & 50.80 & 39.93 & 41.22 & 30176.80 & 14.07 \\
\hline $14-15$ & 49.13 & 50.87 & 39.81 & 41.21 & 31198.45 & 13.10 \\
\hline
\end{tabular}

Source: EPB 